\title{
John of Damascus in the Summa Halensis
}

\author{
The Use of Greek Patristic Thought in the Treatment of the \\ Incarnation
}

\begin{abstract}
This chapter examines the quotations from John of Damascus' De fide orthodoxa contained in the Summa Halensis, specifically in its section on the assumption of human nature in the Incarnation. Starting from contextual observations, the paper moves, in a first step, to an analysis of citations from the Damascene in Peter Lombard's Sentences. The authoritative role of the latter writing meant that its often idiosyncratic use of the Damascene was passed on to later scholastics, such as the authors of the Summa. A detailed consideration of ten quotations from the Damascene in the Summa, which makes up the second part of the paper, reveals a complex pattern of reception. Passages from De fide orthodoxa were often taken out of context, truncated, or both, in order to serve as building blocks in the Summa's own, dialectical presentation of a theological topic. In conclusion, the paper cautions against the conventional assumption equating the number of references to an authority in the Summa with their conceptual influence.
\end{abstract}

The reader of the Summa Halensis is not only confronted with the extraordinary quantity of its literary achievement. Equally intimidating is the number of references made in this work of the early Franciscan school to a vast number of authorities: pagan, Jewish, Muslim, and Christian authors from antiquity up until their own time are cited, often with precise or seemingly precise references to the passages from which these citations have been taken. Among this huge number of intertextual references, quotations from the $8^{\text {th }}$-century Greek-Arabic theologian John of Damascus make up a not inconsiderable part. According to the comprehensive index of citations which the Quaracchi editors of the Summa have prepared, there is a total of 591 references to the work of the Damascene. ${ }^{1}$ Almost all of them are taken from one

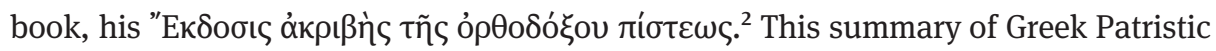
theology had been translated into Latin under the title De fide orthodoxa by Burgundio of Pisa in the mid $12^{\text {th }}$ century. ${ }^{3}$ Its impact on Western scholasticism was nearly

\footnotetext{
1 Doctoris irrefragabilis Alexandri de Hales Ordinis minorum Summa theologica: Indices in tom. I-IV (Quaracchi: Collegium S. Bonaventurae, 1979), 148-50.

2 John of Damascus, Die Schriften des Johannes von Damaskos, vol. 2, Expositio Fidei, ed. Bonifatius Kotter (Berlin/New York: de Gruyter, 1973).

3 Saint John Damascene, De Fide Orthodoxa: Versions of Burgundio and Cerbanus, ed. Eligius M. Buytaert (St Bonaventure, NY: Franciscan Institute, 1955). In what follows, I use this title to refer to both the Greek and the Latin versions of John's treatise.
}

D OpenAccess. (c) 2020 Lydia Schumacher, published by De Gruyter. (c))BY-NC-ND This work is licensed under the Creative Commons Attribution-NonCommercial-NoDerivatives 4.0 License. 
immediate not least because Peter Lombard made heavy use of this work in his four books of Sentences, a work of unrivalled influence in subsequent centuries.

It is immediately evident that both the Lombard and $13^{\text {th }}$-century writers, such as the author of the Summa Halensis, considered John a great authority. His work is cited alongside the most respected Patristic and medieval authorities, such as Augustine or Anselm of Canterbury even though these two thinkers and Augustine especially, admittedly, outrank the Greek theologian. Yet how influential was the Damascene on doctrinal and conceptual developments during this period? This question is much more difficult to answer than might first appear from the massive number of quotations from his work that were incorporated into the writings of his medieval readers. Part of the reason for this lies in the particular citation technique employed by early scholastic authors in which it is often far from evident what the function of a particular authoritative quotation is within a given argument.

One way to address this difficulty is to pay closer attention to individual references within their context. What is quoted? Are quotations faithful to their original context (and indeed their original text, as far as we can make it out)? How are the quoted texts used in their new textual environment? My chapter will contribute to this study which, as far as I can see, has not so far been extensively undertaken, certainly not for the quotations in the Summa Halensis. For practical reasons, I could only analyse a small selection of citations. It is thus inevitable that more general conclusions can only be drawn with caution. Yet I hope that the tendencies emerging from my research may nonetheless be enlightening.

As the basis for my investigation, I have chosen the section in Part 3 of the Summa which deals with the Incarnation. More specifically, I have focussed on those passages in which the Franciscan author deals with the notoriously difficult problem of Christ's assumption of human nature and the character of the ensuing divine-human union. There are obvious reasons for this selection. These problems were at the heart of Eastern doctrinal debate and development between the $5^{\text {th }}$ and the $8^{\text {th }}$ centuries. ${ }^{4}$ John of Damascus' magnum opus offers an excellent summary of the systematic outcome of these debates, at least on the Chalcedonian side. In the Latin West, Christology emerged as a major doctrinal problem during the $12^{\text {th }}$ century. ${ }^{5}$ The amount of sophisticated Christological literature that existed in Latin up until that point which could be utilised in the ensuing discussions was limited. ${ }^{6}$ Nat-

4 Andrew Louth, 'Christology in the East from the Council of Chalcedon to John of Damascus,' in The Oxford Handbook of Christology, ed. Francesca Murphy (Oxford: Oxford University Press, 2015), $139-53$.

5 Lauge Olaf Nielsen, Theology and Philosophy in the Twelfth Century: A Study of Gilbert of Porreta's Thinking and the Theological Expositions of the Doctrine of the Incarnation during the Period 11301180 (Leiden: Brill, 1982), 193-361.

6 The Christological controversy of the first millennium was essentially an Eastern affair in which some Latin theologians participated. Most of the latter, however, were thinkers with deep roots in the Greek intellectual tradition, such as Boethius or Facundus of Hermiane. 
urally, Latin Patristic authorities, such as Augustine or Leo the Great, could be relied on to emphasise the fundamentals of orthodox Christology, but Western authors were to discover what their Greek counterparts had painfully found out half a millennium before, namely, that agreement on the full divinity and humanity of the saviour, together with a commitment to his personal unity, only served to define the terms on which a Christological conflict could be fought but did little to settle it.

It is therefore prima facie unsurprising that early medieval Western thinkers sought out the support of Greek fathers and especially that of Damascus' systematic presentation of the later Chalcedonian settlement. At the same time, any attempt to determine the potential influence of the Damascene on the Summa Halensis must start from the acknowledgement that such an attempt at appropriation faced considerable hermeneutical difficulties. What I mean is that the questions to which John of Damascus' clarifications sought to provide answers were in some ways rather different from the questions that shaped early medieval debates about Christology in the Latin West. Let me therefore begin by sketching more generally-and inevitably with a broad brush-the background to the Christological synthesis the medieval Latin thinkers were encountering in John of Damascus. I will then proceed to offer some observations on the integration of extracts from John's great work in the most influential theological treatise of the period, that is, Peter Lombard's Sentences, before moving on to consider the quotations found in my selections from the Summa Halensis.

\section{The Background: Greek Patristic Christology at the End of the Patristic Era}

The formula adopted by the Council of Chalcedon in 451 always appeared to Western Christians as the perfect, Solomonic judgment in an obviously subtle and complex doctrinal conflict. ${ }^{7}$ By asserting the duality of perfect divinity and perfect humanity, the consubstantiality of Christ with humankind insofar as he was human, and the unity of his personal individuality, the Council seemed to have hit on doctrinal truth in a way that appeared intuitively obvious to many or most. That this solution was credited to the benign, yet powerful influence of the Roman pontiff arguably added to the synod's reputation for exercising superior wisdom in adjudicating the doctrinal conflict at hand. ${ }^{8}$

7 Cf. the formula of 'four gospels and four councils' popularised by Gregory the Great (Epistola 1.24: PL 77:478 A).

8 The enthusiastic acclamation of Leo's Tome at the Council reached its climax in the words, 'Peter

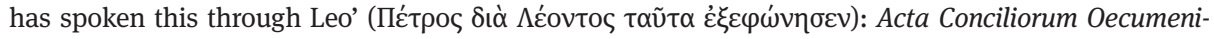
corum, ed. Eduard Schwartz, vol. 2/1/2 (Berlin/Leipzig: de Gruyter, 1933), 81, 23-31. 
It was quite otherwise in the East where the formula adopted by the Council intuitively appeared implausible, even absurd, and certainly wrong to a large number of believers as well as to the most educated theological thinkers. ${ }^{9}$ It is always worth remembering the rather extraordinary fact that this state-sponsored synod did not have any first-rate theological support in the East for more than half a century. This changed from the age of Justinian, and the $6^{\text {th }}$ century already testifies to a growing and increasingly confident group of major Chalcedonian authors, but their arguments were forged while on the defence against opponents who were fully convinced of the superiority of their own case, both in terms of patristic support and in terms of doctrinal and conceptual coherence. In principle, this situation had not changed even by the time of John of Damascus, as the Arabic conquest from the $7^{\text {th }}$ century onwards initially led to a renewed consolidation of non-Chalcedonian Christianity in those areas that were newly liberated from the Chalcedonian dictate of the Byzantine emperors. ${ }^{10}$ It is impossible to appreciate John's account of Christology without taking this context into account.

What is the reason for this radically different history in the East and the West? I will restrain myself from speculating about different religious or intellectual mentalities as this is insignificant for my paper today. Instead, I want to focus on the alleged failures of the Chalcedonian formula, as they can help explain the conceptual approach taken by John of Damascus in his defence of Chalcedonianism. In many ways, the origin of the problem lay in the particular language that had been adopted by the so-called Cappadocian theologians of the late $4^{\text {th }}$ century to resolve the trinitarian controversy. Basil the Great, his friend Gregory of Nazianzus and Basil's younger brother, Gregory of Nyssa, became uniquely influential in later Eastern theology due to their terminological and conceptual response to the doctrinal conflicts that divided the newly Christianised empire in the latter half of the $4^{\text {th }}$ century. ${ }^{11}$

Part of the force their solution took on clearly derived from its cast as a quasiphilosophical theory framed in a way that went beyond its immediate purpose, which was to explain how the three divine hypostases were also and at the same time one single divine ousia or God. ${ }^{12}$ This theory had just enough points of contact

9 Aloys Grillmeier, Christ in Christian Tradition, vol. 2/1, trans. Pauline Allen and John Cawte (Atlanta, GA: John Knox, 1987), 93-317.

10 W.H.C. Frend, The Rise of the Monophysite Movement: Chapters in the History of the Church in the Fifth and Sixth Centuries (Cambridge: Cambridge University Press, 1972), 356-7.

11 Johannes Zachhuber, 'Christology after Chalcedon and the Transformation of the Philosophical Tradition: Reflections on a Neglected Topic,' in The Ways of Byzantine Philosophy, ed. Mikonja Knežević (Alhambra, CA: Sebastian Press, 2015), 89-110.

12 The foundational text is [Basil] Epistola 38. It is read in the editions of Basil's letters, most recently: Saint Basile, Lettres, ed. Yves Courtonne, vol. 1 (Paris: Les Belles Lettres, 1957), 80 -92. Most scholars, however, now accept that the text was authored by Gregory of Nyssa. See most recently: Andrew Radde-Gallwitz, Gregory of Nyssa: Doctrinal Works (Oxford: Oxford University Press, 2018), 116. For a full interpretation of this text in its philosophical context, see Johannes Zachhuber, Human Nature in Gregory of Nyssa: Theological Background and Theological Significance (Leiden: Brill, 1999), 61-93. 
with the prevailing logical accounts in the Aristotelian commentaries to inscribe Christian thought into existing intellectual traditions; it maintained enough independence from those pagan texts to make plausible the claim that this was a new form of Christian philosophy.

According to the Cappadocians, being is universal, but concrete existence is tied to individuals. Ousia or physis is one but has no existence or subsistence apart from individual hypostases. It is perhaps less obvious to see how it floundered on Christology; but it did. ${ }^{13} \mathrm{~A}$ famous battle cry of the opponents of the Chalcedonian solution was that there could be no physis without a hypostasis. ${ }^{14}$ This principle was little more than an application of-or an inference from-the Cappadocian philosophy in which it had been vital to insist that the divine nature existed only and exclusively in the three hypostases of the Godhead.

In Christology, it then seemed to follow that the two natures affirmed by Chalcedon led to two hypostases. But two hypostases were also counterintuitive since the term had been defined as the equivalent to atomon or individual. Hence the popular acceptance of miaphysitism, the belief that there was only one single nature in the Incarnate.

Once this problem was fully recognised on the Chalcedonian side-and this took the better part of a century-the need emerged to explain how two natures could come together in a single hypostasis. The celebrated solution to this problem, as it is presented for example in John of Damascus' work-was the doctrine of the anhypostatic human nature of the saviour-an individuated human nature that yet exists without a hypostasis of its own insofar as it is realised within the hypostasis of the divine Word. ${ }^{15}$

The ingenuity of this solution lies in the fact that it does not entirely break with the Cappadocian theory, as this would have had far-reaching consequences not least for trinitarian doctrine. The ontological link between universal nature and its hypostatic realisations is still maintained, but an additional-and as far as I can see, entirely innovative-ontological layer is introduced between the conceptual individuation through personal properties and actual, concrete, hypostatic existence. ${ }^{16}$

It is arguable that anyone seeking to arrive at a plausible Christology will encounter the difficulty of how the two natures, divine and human, can find a single united existence in the person of Jesus Christ. Yet the specific solution that appealed

13 Cf. Aloys Grillmeier, Christ in Christian Tradition, vol. 1, trans. John Bowden, 2nd ed. (Atlanta: John Knox, 1975), 551-2.

14 Cf. e.g. Leontius of Byzantium, Contra Nestorianos et Eutychianos 1, in Leontius of Byzantium: Complete Works, ed. Brian E. Daley (Oxford: Oxford University Press, 2017), 130, 10 -1; John the Grammarian, Apologia concilii Chalcedonensis IV, in Johannis Caesariensis presbyteri et grammatici, Opera quae supersunt, ed. Marcel Richard (Leuven: Peeters, 1977), 51, 82-3.

15 Cf. Benjamin Gleede, The Development of the Term ENYПОГTATO $\Sigma$ from Origen to John of Damascus (Leiden: Brill, 2012).

16 Cf. Zachhuber, 'Christology after Chalcedon,' 124-6. 
to John of Damascus was not necessarily attractive to those who had never been faced with the particular context of the Eastern Christological debate.

Western Christological debate, by contrast, was initially shaped in the $12^{\text {th }}$ century by the different contributions of Gilbert of Poitiers, Hugh of St Victor, and Abelard. ${ }^{17}$ The problem of the assumption was, following Gilbert, often put into a four-way disjunction: did a person assume a person; or a person a nature; or a nature a person; or a nature a nature. ${ }^{18}$ From the turn of the $13^{\text {th }}$ century onwards, the socalled three opinions (assumptus homo; subsistence; and habitus theory) expounded in Lombard's Sentences were accepted as a starting point by all major discussants even though the third of them was often treated as little more than a theoretical option since it had been officially condemned in $1177 .{ }^{19}$ While the questions raised by these conceptual frames were not unrelated to those addressed by John of Damascus, they were sufficiently distinct to take doctrinal debate in rather different directions.

Notably, the Latin preference for the term persona ${ }^{20}$ gave theologians options their Greek counterparts did not have, as the special connotations of this term allowed the scholastics to concede other dualities in the saviour which in a Greek context would certainly have come dangerously close to affirming two hypostases. ${ }^{21}$ At the same time, the single major element of John's late Chalcedonian system, his emphasis on the possibility of the assumption of anhypostatised human nature, found only a limited echo among his early Western readers.

All this is not to say that the Damascene was without influence on Western Christological debates from the middle of the $12^{\text {th }}$ century onwards. This would certainly be false. ${ }^{22}$ It is, for example, arguable that the relatively swift overall agreement, emerging from the early $13^{\text {th }}$ century, that of the three opinions only the second one, the socalled subsistence theory, was ultimately acceptable, owed something to the proximity between that theory and the account of the Incarnation given by the Damascene. Yet by and large, sweeping claims are difficult and treacherous due to the different historical, cultural and theological contexts that were brought together by John's introduction into the Latin world.

17 Nielsen, Theology and Philosophy.

18 Nielsen, Theology and Philosophy, 164-5.

19 Peter Lombard, Sententiae in IV libris distinctae (hereafter, Sent.) III, dd. 6-7, 2 vols, ed. Ignatius C. Brady, 3rd rev. ed. (Grottaferrata: Editiones Collegii S. Bonaventurae, 1971-81), 2:49-66. Cf. Marcia L. Colish, Peter Lombard, 2 vols (Leiden: Brill, 1994), 1:399-404. For the reception of Lombard and the condemnation of 1177, see Clare Monagle, Orthodoxy and Controversy in Twelfth-Century Religious Discourse: Peter Lombard's 'Sentences' and the Development of Theology (Turnhout: Brepols, 2011). 20 At least since Leo's Tome of 451.

21 See further below at n. 85.

22 Note the useful overview in Milton V. Anastos, 'Some Aspects of Byzantine Influence on Latin Thought in the Twelfth Century,' in Twelfth Century Europe and the Foundations of Modern Society, ed. Marshall Clagett, Gaines Post, and Robert Peynolds, 2nd ed. (Madison, WI: University of Wisconsin Press, 1966), 131-88 = Milton V. Anastos, Studies in Byzantine Intellectual History (London: Variorum, 1979), 149-63. 
It is for this reason that in what follows I shall largely avoid overarching claims and instead attend to the details of the Damascene's reception. Before addressing his citations in the Summa, it will be useful to take a quick glance at the work which both introduced The Orthodox Faith to a larger Western readership and also formed the structural backbone of most subsequent theological discussion. Here, I refer to Peter Lombard's Four Books of Sentences.

\section{John of Damascus in the Book of Sentences}

A major investigation of the way in which the Lombard incorporated quotations from John of Damascus into his Sentences does not seem to exist. ${ }^{23}$ Yet such a study would be highly desirable. In the present place, I cannot obviously highlight more than a few observations on sections that will be important for my subsequent discussion of the Summa Halensis, but I hope that this small selection can serve as an illustration of the bigger picture. As we shall see, the Lombard used texts from Damascus rather liberally and throughout his work in a way intended to solve his own theological questions.

\section{Sentences III, Distinction 2}

My first example is taken from Distinction 2 in Book 3 of the Sentences. ${ }^{24}$ Here, Lombard addresses the question whether Christ took on the whole of human nature and of what the meaning is of the terms 'humanity' and 'human nature'. In addressing this issue, which for him was framed by problems raised by Gilbert of Poitiers, ${ }^{25}$ Lombard makes use of three separate passages in John's book. The first of them, taken from Chapter 48 (III 4) is relatively straightforward and works well with his argumentative purpose. ${ }^{26}$ He then, however, moves on to another passage, which he does not identify, and from there, things become much more problematic.

Lombard's claim is that 'nature is not accepted in Christ in the same way as when it is said that there is one nature of all human beings' ${ }^{27}$ In support of this statement, he now cites a lengthy passage from The Orthodox Faith, Chapter 47.5 (III 5). In this section, the Damascene argues against his monophysite opponents who, he al-

23 The most detailed account is in Anastos, 'Byzantine Influence'. Cf. also Eligius M. Buytaert, 'St. John Damascene, Peter Lombard and Gerhoh of Reichersberg,' Franciscan Studies 10 (1950): 323-43; Colish, Peter Lombard, 1:126-8, 215-6, 420.

24 Peter Lombard, Sent. III, d. 2, c. 1 (Brady, 2:27-9).

25 Nielsen, Theology and Philosophy, 245-6.

26 Peter Lombard, Sent. III, d. 2, c. 1, 2 (Brady, 2:28.7-12).

27 Peter Lombard, Sent. III, d. 2, c. 1, 3 (Brady, 2:28.13-4): 'Natura enim non sic accipitur in christo ut cum dicitur una natura esse omnium hominum.' 
leges, did not properly distinguish the terms nature and hypostasis. Calling all human beings 'one nature', Damascus argues, we do not in this case consider them qua soul and body, as those two ontologically opposed constituents of the human person could not possibly be jointly understood as 'one nature'. Instead, we speak of the many individuals who are all defined in the same way as possessing a rational soul and a body. In the case of Jesus, however, this consideration makes no sense as there is no species of saviours, but his case is unique-there never was and never will be another.

Let us leave to one side whether John's argument would convince a dyed-in-thewool monophysite. More pertinent for the present topic is how Peter Lombard used this passage, which is nothing short of extraordinary. We can easily appreciate that the Lombard was less concerned with Eastern miaphysites than his Greek source, but he could only marshal this passage for his own ends by making a small but decisive change to its wording as well as by truncating it at the end.

Peter Lombard, Sentences ${ }^{28}$

Natura enim non sic accipitur in christo ut cum dicitur una natura esse omnium hominum. Quod euidenter idem ioannes ostendit, differentem rationem dicti assignans cum natura humana in christo nominatur, et cum una dicitur natura omnium hominum.

Ait enim: Cum unam hominum naturam dicimus, sciendum est quod non considerantes ad animae et corporis rationem hoc dicimus. Impossibile enim est unius naturae dicere domini corpus et animam ad inuicem comparata.

Sed quia plurimae personae hominum sunt, omnes autem eandem suscipiunt rationem naturae, omnes enim ex anima et corpore compositi sunt, et omnes naturam animae participant et substantiam corporis possident,

John of Damascus, De fide or-
thodoxa (Burgundio transla-
tion)

John of Damascus, De fide orthodoxa (Cerbanus translation) $)^{30}$
Sed hoc est quod facit haereticis errorem, quod idem dicunt naturam et hypostasim.

Quia autem unam hominum naturam inquimus, sciendum quod non inspicientes in eam quae animae et corporis rationem hoc dicimus. Impossibile enim unius naturae dicere animam et corpus ad invicem comparata.

Sed, quia plurimae hypostases (id est personae) hominum sunt, omnes autem eandem suscipiunt rationem naturae;-omnes enim ex anima sunt compositi et corpore, et omnes naturam animae participant et substantiam corporis possident;
Quoniam autem unam hominum naturam esse dicimus, sciendum est quod non consideranter ad animae et corporis rationem hoc dicimus. Impossibile enim est unius naturae dicere corpusque Domini et animam ad invicem comparata.

Quoniam autem plures personae hominum sunt et omnes eandem recipiunt rationem substantiae,-omnes ex anima et corpore compositae sunt et omnes naturam animae amplectuntur et substantiam corporis possident,

28 Peter Lombard, Sent. III, d. 2, c. 1, 3 (Brady, 2:28.13-29.2).

29 John of Damascus, De fide orth. 47.5 [III 3] (Buytaert, 176.49-64).

30 John of Damascus, De fide orth. 47.5 [III 3] (Buytaert, 394.45-59). 
communem speciem plurimarum et differentium personarum unam naturam dicimus, uniuscuiusque scilicet personae duas naturas habentis et in duabus perfectae naturis, animae scilicet et corporis.

In domino autem iesu christo non est communem speciem accipere. Neque enim factus est, nec est, nec aliquando fiet alius. Sed christus ex deitate et humanitate, in deitate et humanitate, deus perfectus est, idem et homo perfectus
- communem speciem plurimarum et diversarum hypostaseon (id est personarum) unam naturam inquimus, unaquaque scilicet hypostaseos (id est persona) duas naturas habente et in duabus perfecta naturis, animae dico et corporis.

In Domino autem nostro lesu

Christo non est communem

speciem suscipere. Neque enim

generatus est, neque est, neque unquam generabitur alius

Christus ex deitate et humani-

tate, in deitate et humanitate

Deus perfectus idem et homo

perfectus.

Hinc non est dicere unam naturam in Domino nostro lesu

Christo.
- communem speciem plurimarum differentium personarum unam naturam dicimus esse, uniuscuiusque videlicet personae duas naturas habentis, et quae duabus perficitur naturis, animae dico et corporis.

Sed in domino nostro lesu Christo non est communem speciem accipere. Neque enim fuit, neque est, neque aliquando erit alius Christus ex deitate et humanitate, et in deitate et humanitate, Deus perfectus et homo perfectus. Ex quo non est dicere unam naturam esse in Domino nostro lesu Christo.

According to Peter's reading, the Damascene's text demonstrates that 'we assign a different principle of speech when we speak of the human nature in Christ and when we say that the nature of all human beings is one. ${ }^{31}$ The key word here is clearly 'human nature' (humana natura). It would arguably still be correct, albeit liable to misunderstanding when taken out of context, to paraphrase Damascus as saying that 'nature' in Christ (as understood by the miaphysites) does not mean the same as universal human nature. By adding 'human', however, the Lombard represents his source as postulating a difference between Christ's humanity and that of the remainder of humankind.

This point is further substantiated by Peter's attribution to the Damascene of the view that it was 'impossible to call the soul and body of the Lord of one nature when compared with one another'. This is not particularly clear, but in light of Peter's preceding summary of what, in his opinion, John of Damascus was saying in this passage, he must clearly have intended it to mean that Christ's body and soul could not be considered of one nature with the remainder of humankind. The problem is that the Damascene, for obvious reasons, never wrote such a thing. Rather, the sentence quoted by the Lombard states, both in Greek and in the Burgundio translation that it was 'impossible to call soul and body of one nature when [they are] compared with one another'. ${ }^{32}$ In other words, Peter's idiosyncratic reading of De fide orthodoxa is here sustained by the word domini which is added to the original text of his source.

31 Peter Lombard, Sent. III, d. 2, c. 1, 3 (Brady, 2:28.15-6).

32 John of Damascus, De fide orth. 47.5 [III 3] (Kotter, 112.42-3 and 176.52). 
The Lombard was not, however, personally responsible for this addition. Rather, he found it in the older, partial translation of John's work, attributed to a certain Cerbanus, which he initially used before the full translation by Burgundio became available. ${ }^{33}$ Eligius M. Buytaert has done much to elucidate how the Lombard corrected his citations with the help of the later version once he was able to consult it. As Buytaert shows, however, the Lombard did this in a rather unsystematic fashion that resulted in an idiosyncratic text that often displayed a unique blend of the two versions. ${ }^{34}$ The present passage offers an intriguing example of this practice insofar as it indicates that the Lombard's encounter with the Burgundio version could have substantive implications for the use he had previously made of the Damascene's argument in his own text.

Peter's use of the Cerbanus translation does not, however, fully explain his problematic use of the Damascene in the present passage. The purpose of John's argument is evident, in the Greek original as well as in both translations, from the concluding line which states that 'one therefore must not speak of one nature in our Lord Jesus Christ. ${ }^{35}$ The Lombard, however, omits this statement with the result that the preceding sentence, according to which 'one must not postulate a common species in the saviour', appears as the summary of the whole argument. The sense it is arguably meant to convey in the Book of Sentences would perhaps best be expressed by using the definite article in the English translation: 'one must not postulate the common species [i.e. humanity] in the saviour.'

I must admit that I do not know why it could have appeared attractive to the Lombard to credit John of Damascus with the extraordinary view that Christ's humanity was categorically different from ours. ${ }^{36}$ As we shall see, however, the consequences of this integration of a Greek patristic argument into what was to become the most influential scholastic text were far-reaching.

33 John of Damascus, De fide orth. 47.5 [III 3] (Buytaert, 394.47-9). From Kotter's edition it appears, moreover, that some Greek manuscripts contained the additional toṽ kupíov: De fide orth. 47.42 app. (Kotter, 112).

34 Saint John Damascene, De Fide (see above, n. 3), XII-XIII.

35 John of Damascus, De fide orth. 47.5 [III 3] (Kotter, 113.53-4; Buytaert, 176.65 and 394.59-60). 36 According to one of his early critics, John of Cornwall, this passage illustrates Peter's Christological 'nihilism'. John may have been the first to note the Lombard's misleading use of the Damascene: N.M. Häring, 'Eulogium ad Alexandrum Papam tertiam of John of Cornwall,' Medieval Studies 13 (1951): 278. If it is the case, as Häring seems to think, that John simply culled his Patristic quotations from the Sentences, it is remarkable that his text omits the added 'domini'. John's criticism of the Lombard is summarily dismissed by Colish, Peter Lombard, 1:431. Cf. also: Monagle, Orthodoxy and Controversy, 106-7. 


\section{Sentences III, Distinction 5}

My second example is taken from the fifth distinction in the same book. This is a crucial section which arguably shows how Greek thought had an influence on Western Christological thought. Once again, however, it is crucial to consider the details.

The explicit purpose of the distinction is to consider 'whether person or nature assumed person or nature', as Lombard put it in the heading. The question at once betrays that Peter here follows a problematic originating from the great but idiosyncratic $12^{\text {th }}$-century thinker, Gilbert of Poitiers. According to Gilbert, the theological problem of the Incarnation came down to a four-way disjunction: did a person assume a person; or a person a nature; or a nature a person; or finally a nature a nature? Gilbert's argument cannot be rehearsed here, but for him, only one of those four options was acceptable: that a person assumed a nature. ${ }^{37}$

Lombard generally follows Gilbert's intuitions in his Christology-and in fact, the fourfold disjunction became through Lombard a widely-accepted starting point for later presentations of the doctrine, but Peter also saw that Gilbert's insistence on the exclusive acceptability of persona assumpsit naturam conflicted with the Greek tradition as represented by John, for which there was no contradiction at all between the idea that the hypostasis of the Logos assumed human nature and the notion that divine nature took on human nature. In the present distinction, Lombard clearly seeks to integrate the Eastern perspective into the Gilbertian framework from which he starts.

As his proof text, he this time chooses a section in The Orthodox Faith that appears an obvious selection: after all, Chapter 50 (III 4) is entitled, 'Why the whole divine nature in one of its hypostases is united to the whole human nature and not a part to a part. ${ }^{38}$ It may nonetheless be useful to look more closely at what the purpose of this section is in John of Damascus before turning to the way Peter Lombard employs it in his own argument.

For the Damascene, the context is once again the conflict with the miaphysite opponents of Chalcedon. A prominent (and in my view perfectly legitimate) argument against the dyophysitism of the Council was that its proponents neglected individuation of universal natures when speaking of the Incarnation. They should acknowledge, their opponents urged, that the divinity and humanity in Christ had to be 'particular natures' as otherwise they could not avoid the consequence that the whole Trinity became Incarnate in the whole humanity. ${ }^{39}$ As we will see later, this argument was not entirely without effect on later Chalcedonians, such as John of

37 Gilbert of Poitiers, Expositio in Boecii Librum Contra Euticen et Nestorium 4.108, in The Commentaries on Boethius by Gilbert of Poitiers, ed. Nikolaus M. Häring (Toronto: Pontifical Institute of Medieval Studies, 1966), 310.52-9.

38 John of Damascus, De fide orth. 50 [III 6] (Buytaert, 186): 'Quoniam omnis divina natura in una sui hypostaseon (id est personarum) unita est omni humanae naturae, et non pars parti.'

39 Cf. Zachhuber, 'Christology after Chalcedon,' 114. 
Damascus, but they never conceded the need for particular natures which, they felt, would open them up to the charge of tritheism. Chapter 50 of The Orthodox Faith is essentially constructed to counter this powerful argument. The Damascene uses both philosophical and theological considerations to show that the union must involve universal natures both on the divine and the human planes. Philosophically, he holds that natures are universal even though they are seen (only) in individuals. Theologically he alludes to the so-called physical doctrine of salvation, i.e. the idea that Christ's redemptive act spreads to humankind via their common participation in universal human nature. ${ }^{40}$

In this context, the Damascene even manages to include a brief justification for the notorious mia-physis formula, 'according to blessed Athanasius and Cyril': the one Incarnate nature of the Word, he argues, merely refers to divine nature as encountered or realised in the hypostasis of the Logos. ${ }^{41}$

From this brief account, it should be obvious that, while the chapter clearly stated the position Peter Lombard was interested in, namely, the assumption of human nature by divine nature, it did so in a rather different context and consequently with the addition of material that was at the least not directly supportive of Peter's argumentative purpose in the present distinction. It is intriguing to observe how he dealt with this problem. First of all, he chose around 80 words from the whole chapter and wove them into one long quotation whose precise limits cannot have been easy to gauge for a reader without immediate access to the Latin text of The Orthodox Faith:

Peter Lombard, Sentences ${ }^{42}$

John of Damascus, De fide orthodoxa ${ }^{43}$

Qui sensus ex uerbis ioannis damasceni confirmatur, qui totam diuinam naturam in una hypostasium incarnatam esse euidenter asserit, dicens: In humanatione dei uerbi aimus omnem et Ita et in humanatione unius sanctae trinitatis Dei perfectam naturam deitatis in una eius hypostaseon incarnatam esse, id est unitam humanae naturae, et non partem parti.

Verbi aimus omnem et perfectam naturam deitatis, in una eius hypostaseon (id est personarum), unitam esse humanae naturae, et non partem parti.

Omni enim humanae naturae aimus unitam esse omnem deitatis naturam uel substantiam.

Omni autem humanae naturae aimus unitam esse omnem deitatis substantiam.

Item: Eadem est natura in singula hypostaseon, id est personarum. Et quando dicimus naturam

Eadem igitur natura in unaquaque hypostaseon (id est personarum) consideratur. Et quando di-

40 Reinhard M. Hübner, Die Einheit des Leibes Christi bei Gregor von Nyssa: Untersuchungen zum Ursprung der ,physischen“ Erlösungslehre (Leiden: Brill, 1974).

41 John of Damascus, De fide orth. 50.6 [III 6] (Buytaert, 190.75-191.1). The (partial) acceptance of this formula is indicative of what scholars have called neo-Chalcedonianism: Marcel Richard, 'Le Néo-chalcédonisme,' Mélange de Science Religieuse 3 (1946): 156-61.

42 Peter Lombard, Sent. III, d. 5, c. 1, 12 (Brady, 2:45.24-46.6).

43 John of Damascus, De fide orth. 50 [III 6] (Buytaert, 187.28-188.31.39-41 and 190.73-191.83). 
uerbi incarnatam esse, secundum beatos et athanasium et cyrillum, deitatem dicimus esse unitam carni.

Et unam naturam dei uerbi incarnatam confitemur. ${ }^{44}$ cimus "naturam Verbi incarnatam esse", secundum beatos et Athanasium et Cyrillum deitatem dicimus unitam esse carni.

Ideo non possumus dicere: natura Verbi passa est; non enim passa est deitas in ipso.

Dicimus autem humanam naturam passam esse in Christo, non tamen omnes hypostases (id est personas) hominum ostendentes; et humana natura passum esse confitemur Christum. Quare, naturam Verbi dicentes, ipsum Verbum significamus.

Verbum autem et quod commune est substantiae possidet, et quod proprietatis est habens hypostaseos, id est personae.
Verbum autem et quod commune substantiae habet, et quod proprium hypostaseos (id est personae).

Ex his manifeste ostenditur quod natura diuina incarnata est; unde et eadem uere dicitur suscepisse humanam naturam.

The excerpt by and large illustrates Lombard's main point that Damascus affirms the assumption of human nature by divine nature. One intriguing quirk, however, should be mentioned. Included in Peter's selections from the chapter are John's words about Athanasius' [in reality Apollinarius'] and Cyril's use of the formula that 'the nature of the Word became incarnate'. ${ }^{45}$ This was arguably unnecessary and might cause more harm than good. What is more surprising, however, is that Peter glosses John's words with a much more unequivocally monophysite formula: 'and we confess one nature of the Incarnate Word of God' (Et unam naturam dei uerbi incarnatam confitemur). How this sentence came to be added here is not easy to explain. Perhaps it was a Gloss on The Orthodox Faith 55.2 where John cites the mia-physis formula from Cyril's second letter to Succensus. ${ }^{46}$ It certainly did raise eyebrows among the Lombard's later readers, including Alexander of Hales.

This brief examination of the use of two Damascene texts in key passages of Book 3 of Lombard's Sentences seems to justify the conclusion that Peter's role in introducing Damascus into Latin theological debate was not without its ambiguities. On the one hand, there is no doubt that through The Orthodox Faith, the Greek Patristic tradition was permitted to weigh in on major theological questions and to provide alternative perspectives and answers. On the other hand, it should have become clear that readers who relied on the Sentences to access the work of the Damascene were presented with excerpts that one would be kind to describe as tendentious. As we have seen, Lombard excerpted, took out of context, and even changed wording in

44 Cf. John of Damascus, De fide orth. 55.2 [III 11] (Buytaert, 205.32-4).

45 Cf. Anastos, 'Byzantine Influence,' 158-9 and 184, n. 124.

46 This was, apparently, Anastos’ assumption. See previous note. 
order to make his source fit what he needed it to say. At the same time, he also introduced quotations that were seemingly unrelated to their context in the Sentences and which, therefore, invited speculative interpretations unless they were recontextualised within the full text of Damascus' great work.

\section{The Use of the Damascene in the Summa Halensis}

\section{General observations}

For the purposes of this paper, I limit myself to the fourth quaestio, the last of the first tractate of the third part of the Summa Halensis, entitled De actu incarnationis. It covers roughly 50 pages in the Quaracchi edition. ${ }^{47}$ For purely practical reasons, I will leave out of consideration Members 2 and 3 of Distinction 3 (de coassumptis). ${ }^{48}$ In the remaining section of the text, the Summa explicitly refers to John of Damascus ten times. ${ }^{49}$ Before looking at some of those references in more detail, let me make a number of more general observations.

First, of these ten quotations, only two are cited with full references to a book and chapter of The Orthodox Faith. ${ }^{50}$ All eight others are simply introduced by formulae such as dicit Ioannes Damascenus ${ }^{51}$ or auctoritas Ioannis Damasceni. ${ }^{52}$ As it happens, the two that are more specific references are quotations from one and the same passage albeit of different length. It is probably no coincidence that this very passage is cited in full in Alexander's Gloss on Lombard's Sentences, Book 3, Distinction 5, ${ }^{53}$ all the more so since both the Summa and the Gloss identify it as taken from Damascus III 7 (while in our edition it is III 11). ${ }^{54}$

47 Alexander of Hales, Doctoris irrefragabilis Alexandri de Hales Ordinis minorum Summa theologica (SH), 4 vols (Quaracchi: Collegium S. Bonaventurae, 1924-48), Vol IV, P1, In1, Tr1, Q4, pp. 48-95. 48 SH IV, P1, In1, Tr1, Q4, Ti1, D3, M2-3, pp. 62-8.

49 All in SH IV, P1, In1, Tr1, Q4: SH IV, P1, In1, Tr1, Q4, Ti1, D1, C2, p. 50; SH IV, P1, In1, Tr1, Q4, Ti1, D2, C1, p. 51; SH IV, P1, In1, Tr1, Q4, Ti1, D2, C2, p. 52; SH IV, P1, In1, Tr1, Q4, Ti1, D2, C3, p. 53; SH IV, P1, In1, Tr1, Q4, Ti1, D2, C4, p. 54; SH IV, P1, In1, Tr1, Q4, Ti1, D2, C5, p. 56; SH IV, P1, In1, Tr1, Q4, Ti1, D2, C5, p. 57; SH IV, P1, In1, Tr1, Q4, Ti1, D3, M4, C3, Ar3, p. 76; SH IV, P1, In1, Tr1, Q4, Ti1, D3, M4, C3, Ar5, Pr2, p. 80; SH IV, P1, In1, Tr1, Q4, Ti2, C4, p. 87.

50 SH IV, P1, In1, Tr1, Q4, Ti1, D2, C1, p. 51: ‘auctoritas Ioannis Damasceni, III libro, cap. 11'. SH IV, P1, In1, Tr1, Q4, Ti1, D2, C4, p. 54: 'per auctoritatem Ioannis Damasceni, III libro, cap. 7’.

51 E.g. SH IV, P1, In1, Tr1, Q4, Ti1, D1, C2, p. 50.

52 E.g. SH IV, P1, In1, Tr1, Q4, Ti1, D2, C3, p. 53.

53 Alexander of Hales, Magistri Alexandri de Hales Glossa in quatuor libros Sentiarum Petri Lombardi (hereafter, Glossa) III, d. 5, 14 (Quaracchi: Collegium S. Bonaventurae, 1951-57), 3:61-2. The correspondence is with SH IV, P1, In1, Tr1, Q4, Ti1, D2, C4, p. 54.

54 According to Buytaert, 'the numbering of these chapters, in many codices, is very disturbed.' Burgundio himself had used John's original division into chapters: Saint John Damascene, De Fide (see above, n. 3), XLIV. 
This brings me to my second observation. There is little evidence that the writers of the Summa took any of these quotations directly from The Orthodox Faith. In addition to the two quotations the authors found in Alexander's Gloss, there are seven that are taken from the Sentences. ${ }^{55}$ They include some of the passages I have discussed earlier and to which I shall return. Among these seven, there is one quotation that is not by the Damascene at all but conflates an argument from Lombard with the reference the latter had made to Damascus in order to support his own claim. ${ }^{56}$ The conflation, however, was not the original work of the Franciscan author of the Summa who in this case simply copied William of Auxerre's Summa Aurea. ${ }^{57}$ This leaves one single quote which I have been unable to locate, ${ }^{58}$ but I suspect that it was also taken from a secondary source.

Third, it is interesting that all of John's citations are employed in order to oppose the evidently orthodox thesis. The caveat, of course, has to be that this is a small selection; I have no doubt that there are examples to the contrary. Nonetheless, this practice marks a stark contrast to Lombard's book in which John's work is introduced in support of the author's own contentions. I shall come back to this observation, as I will argue that it throws a fascinating spotlight on what one might call the citation technique of the Summa.

\section{The Quotations}

In a next step, I shall consider some of those citations in more detail. I will restrict myself here to a small sample. This is possible partly because some quotations are less remarkable than others. In some cases, there is also more than one reference to the same passage from the Damascene's work.

55 All in SH IV, P1, In1, Tr1, Q4: SH IV, P1, In1, Tr1, Q4, Ti1, D2, C2, p. 52; SH IV, P1, In1, Tr1, Q4, Ti1, D2, C3, p. 53; SH IV, P1, In1, Tr1, Q4, Ti1, D2, C5, p. 56; SH IV, P1, In1, Tr1, Q4, Ti1, D2, C5, p. 57; SH IV, P1, In1, Tr1, Q4, Ti1, D3, M4, C3, Ar3, p. 76; SH IV, P1, In1, Tr1, Q4, Ti1, D3, M4, C3, Ar5, Pr2, p. 80; SH IV, P1, In1, Tr1, Q4, Ti2, C4, p. 87.

56 SH IV, P1, In1, Tr1, Q4, Ti1, D3, M4, C3, Ar5, Pr2, p. 80. Cf. Peter Lombard, Sent. III, d. 22, c. 3, 2 (Brady, 2:139.13-25).

57 William of Auxerre, Summa Aurea III, tr. 9, c. 2, 7 vols, ed. Jean Ribaillier, Spicilegium Bonaventurianum, 16-20 (Paris: Editions du Centre National de la Recherche Scientifique (CNRS); Grottaferrata: Editiones Collegii S. Bonaventurae, 1980-7), 4:108. The same misattribution is to be found in Alexander of Hales, Glossa III, d. 22, 12, 3:94.12-4.

58 SH IV, P1, In1, Tr1, Q4, Ti1, D1, C2, p. 50. The reference is to John of Damascus, De fide orth. 8.17 [I 8] (Buytaert, 44.279-81). 
The first case I want to consider is the Summa's use of Chapter 55 (III 11) of the Orthodox Faith. As I have already pointed out, the two references to texts from this chapter are the only instances in my selection of texts for which the author gives exact references in the Damascene's work. I have also mentioned that Alexander cited this very text in his Gloss indicating that he considered it John's solution to the problem of universals.

This chapter in the Damascene's great work is indeed a fascinating example of Patristic philosophy. ${ }^{59}$ We have seen that John adamantly defended the traditional rejection by Chalcedonians of 'particular natures'. And yet, he follows Leontius of Jerusalem in stipulating an alternative form of individuated nature. Leontius called

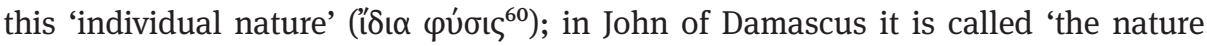
that is seen in the individual'61 and is described as 'the same [nature] wholly with added accidents in one single hypostasis'. ${ }^{62}$ This individuated nature is contrasted with the abstracted universal 'after the many' (to use the conventional term) which is merely 'cogitated in empty contemplation'63 and the universal 'in the many' which, according to John, is common to all individuals of the same species. ${ }^{64}$

The common view of the late ancient Aristotelian commentators was that the universal 'in the many' was no true universal because it was already modified by differences. ${ }^{65}$ This precisely was the reason why many Greek fathers rejected such a concept of particular substance. By contrast, therefore, Damascus' concept of the nature in the individual emphasises that it is eadem, 'the same', as the shared universal, but with accidents.

I cannot discuss here quite how he thought this could work at the philosophical level, ${ }^{66}$ but I need to add two observations before moving on to consider the use of this text by the Summa: first, theologically it helps John explain how the Incarnation is not predicated of universal human nature with the consequence that God became flesh in all human individuals, and yet the individual nature in Christ is identical

59 For a detailed discussion see Richard Cross, 'Perichoresis, Deification, and Christological Predication in John of Damascus,' Medieval Studies 62 (2000): 81-4.

60 Leontius of Jerusalem, Adversus Nestorianos 1.20 (PG 86/1:1485C-D). Cf. Zachhuber, 'Christology after Chalcedon,' $126-6$.

61 John of Damascus, De fide orth. 55 [III 11] (Buytaert, 203.10-1): 'in atomo considerata natura'. 62 John of Damascus, De fide orth. 55 [III 11] (Buytaert, 203.9-10): 'totaliter eadem in assumptione accidentium in una hypostasi'.

63 John of Damascus, De fide orth. 55 [III 11] (Buytaert, 203.6): 'nuda contemplatione cogitatur'. 64 John of Damascus, De fide orth. 55 [III 11] (Buytaert, 203.7): 'communiter in omnibus homoidesi'. 65 Simplicius, In Aristotelis Categorias Commentarium, ed. Karl Kalbfleisch (Berlin: Reimer, 1907), 83, $12-14$.

66 Cf. for this Cross, 'Perichoresis'; Johannes Zachhuber, 'Universals in the Greek Church Fathers,' in Universals in Ancient Philosophy, ed. Riccardo Chiaradonna and Gabriele Galuzzo (Pisa: Edizione della Normale, 2013), 465-9. 
with that of all other people thus making him, as he says alluding to Rom. 11:6, the 'first fruits' of humanity.

Second, it is again theologically vital for John of Damascus that this individual nature is not the same as the hypostasis. In fact, this is the major conceptual innovation: the Cappadocian theory had identified individuation through properties with the concrete existence of the particular hypostasis; ${ }^{67}$ the late Chalcedonian theory, by contrast, draws a distinction between individuation 'in the abstract' as it were and concrete existence. The theological interest is obvious: to maintain Christ's fully individuated humanity without conceding a second hypostasis in the Incarnate.

In the Summa, this chapter is cited twice; both quotations occur in the section I am focussing on. ${ }^{68}$ In the first one, the Damascene is introduced as seemingly testifying against the statement that human nature was assumed in the Incarnation. ${ }^{69}$ This of course is nearly the exact opposite of what John attempted to express in this section, and the author of the Summa can only make his point by reducing John's statement to the interpretation he rejects without mentioning his own solution: 'The Word did not assume the nature that is contemplated in empty thought nor that which is seen in the species. ${ }^{70}$

Once considered in its context, however, the use of these words from The Orthodox Faith by the Franciscan author may seem slightly less absurd than could appear at first sight. John's testimony is introduced to neutralise the supreme authority of Boethius who in his treatise Against Eutyches and Nestorius had offered four definitions of the term natura. ${ }^{71}$ The fourth of those defines nature as 'the specific difference which informs any given thing',72 the Chalcedonian definition that Christ is constituted of two natures, according to Boethius, is based on this definition of natura.

It seems to me that the Summa rightly points to a tension between earlier and later Chalcedonians. Boethius, like many $6^{\text {th }}$-century Chalcedonians ${ }^{73}$ was content to argue that in Christ, two universal natures, divinity and humanity, were jointly individuated. By the time of John of Damascus, however, Chalcedonians had conceded what their opponents had been saying all along: that such a view would imply that the whole Trinity took flesh in the whole humanity. As a matter of fact, as we have

67 Zachhuber, 'Universals,' 468-9.

68 In their index, the editors identify a further place where the author arguably alludes to this section but without direct citation: SH IV, P1, In1, Tr1, Q2, Ti1, D2, M1, C3, p. 29. This passage would merit further consideration than can here be given.

69 SH IV, P1, In1, Tr1, Q4, Ti1, D2, C1, p. 51: 'Relinquitur ergo quod non potest dici "assumpsit humanam naturam".'

70 SH IV, P1, In1, Tr1, Q4, Ti1, D2, C1, p. 51: 'Verbum non eam, quae nuda consideratione contemplatur, naturam assumpsit neque eam, quae in specie consideratur.'

71 Boethius, Contra Eutychen et Nestorium 1 (PL 64:1341B-1342C).

72 Boethius, Contra Eutychen et Nestorium 1 (PL 64:1342C): 'natura est unamquamque rem informans specifica differentia.'

73 Cf. Zachhuber, 'Universals,' 457-8. 
seen, John's text continues with that precise point directly after the Summa ends its quotation.

The Franciscan author thus could agree with the Damascene in criticising Boethius' definition of nature. This does not mean, however, that he shared John's own view; in fact, he may have decided for this very reason to truncate his quotation before the Damascene could even present his own solution. The Summa Halensis presents its own answer by proposing another meaning of natura according to which the Incarnation was to be understood: 'Nature is that from which the being of a natural thing comes or from which a thing is born. ${ }^{74}$

In this sense, the text explains rather succinctly, soul and body can each be called 'nature' insofar as the human being is constituted out of them. The nature the Word assumed in the Incarnation thus is not universal but that of which an individual human being is. Whatever the origin of this idea, ${ }^{75}$ it is not the thought of John of Damascus.

The author of the Summa returns to the same passage in The Orthodox Faith when discussing the question of whether Christ assumed a human person. This time, he cites John's argument in full length, though with some omissions:

The Word did not assume the nature that is contemplated in empty thought, for this would not be an Incarnation but the delusion of an Incarnation. Nor [did he assume] that which is seen in the species, but that which is in the individual. For he took on the first fruits of our dough (lat. massa from Greek $\varphi v ́ \rho \alpha \mu \alpha$; cf. Romans 11:6), which did not subsist by itself or existed previously as an individual and was thus assumed by him but exists in the Son's own hypostasis. ${ }^{76}$

What is the Summa's interpretation of this passage? The author argues that, since a person is 'the individual substance of a rational nature', the Damascene clearly indicates that a human person would have been taken on by the Logos in the Incarnation. ${ }^{77}$ This, however, is clearly not the orthodox view, as it would entail a duality of persons in the Incarnate. ${ }^{78}$

74 SH IV, P1, In1, Tr1, Q4, Ti1, D2, C1, p. 51: [Natura est] 'ex qua fit esse rei naturalis vel ex quibus est res nata'.

75 The language is certainly reminiscent of Gilbert of Poitiers: cf. Nielsen, Theology and Philosophy, 47-9.

76 SH IV, P1, In1, Tr1, Q4, Ti1, D2, C4, p. 54: 'Verbum incarnatum Deus neque eam, quae nuda contemplatione consideratur, naturam assumpsit: non enim hoc est incarnatio, sed fictio incarnationis; neque eam, quae in specie consideratur, sed eam, quae in atomo; primitias enim assumpsit nostrae massae, non secundum seipsam iam subsistentem et atomum existentem prius et ita ab ipso assumptam, sed in ipsa Filii hypostasi existente.'

77 SH IV, P1, In1, Tr1, Q4, Ti1, D2, C4, p. 54: 'Igitur assumpsit "naturam in atomo"; sed natura existens in atomo est persona; ergo assumpsit personam: persona enim est "rationalis naturae individua substantia", quod convenit naturae in atomo.'

78 SH IV, P1, In1, Tr1, Q4, Ti1, D2, C4, p. 55: 'Si persona assumpta est, necesse est in Christo duas esse personas, quia non potest dici absorberi persona humana in assumendo, cum non fuerit prius persona quam assumpta; manent igitur in Christo differentes naturae et diversae personae; non est igitur 
We have thus a case that is rather similar to the one previously analysed. An assumption is imputed to Damascus that was clearly not his own, but at the same time, a well-observed tension between his position and the earlier Chalcedonianism of Boethius is exploited to neutralise the latter authority. In other words, the quotation from The Orthodox Faith serves to highlight that on Boethius' classical definition of persona, it might be inevitable to postulate a human person in the Incarnation; an evident reductio ad absurdum.

Once again, therefore, the use of Damascus' authority is not without subtlety, but his usefulness is limited to that of a strategic weapon against the authority of Boethius. The Summa's author himself endorses an alternative that owes nothing to the Damascene, namely, his celebrated theory of person as a moral term denoting dignity and nobility. ${ }^{79}$ According to this theory, which the Franciscan author found in William of Auxerre's Summa Aurea ${ }^{80}$ and which in its fundamentals goes back to the $5^{\text {th }}$-century Semipelagian, Faustus of Riez, ${ }^{81}$ Christ's single personality is justified by the greater dignity of the divine person which 'consumes' the person of lower rank on the principle persona consumpsit personam, which the Summa (and before it William of Auxerre) intriguingly believed to have been mandated by the Council of Nicaea. ${ }^{82}$

This Christological theory permitted the Summa to concede that Christ qua humanity possessed incommunicabilitas and thus constituted a separate individual and, in all but name, a separate hypostasis. ${ }^{83}$ Damascus' text is understood along those lines: from his mention of the nature in the individual, the Franciscan author argues, 'it does not follow that he assumes a person because the word atomon, which is the same as individual, only signifies the distinction of singularity and incommunicability, but not dignity on which the principle of personhood is based.84

From an Eastern perspective, it is tempting to compare here the approach taken by the Antiochenes and later so-called Nestorians, who similarly felt they had to con-

unum in natura nec unum in persona. Relinquitur igitur quod non est unio Dei ad hominem nisi sicut d in aliis hominibus; quod est absurdissimum. Relinquitur igitur quod persona non est assumpta.' 79 For the historical background of this discussion, see Magdalena Bieniak, The Soul-Body Problem at Paris, ca. 1200-1250: Hugh of St-Cher and his Contemporaries (Leuven: Leuven University Press, 2010), $48-57$.

80 William of Auxerre, Summa Aurea III, tr. 1, c. 3, q. 8 (Ribaillier, 4:36.53-38.2).

81 Faustus of Riez, De spiritu sancto 2.4 (PL 62:29C).

82 SH IV, P1, In1, Tr1, Q4, Ti1, D3, M4, C3, Ar4, p. 78. Cf. William of Auxerre, Summa Aurea III, tr. 1, c. 3, q. 8 (Ribaillier, 4:36.41-3).

83 SH IV, P1, In1, Tr1, Q4, Ti1, D2, C4, p. 55: 'Dicendum ergo quod prima distinctio est in anima Christi, scilicet singularitatis, et etiam in corpore; prima et secunda est in composito ex anima et corpore, quae potest notari, cum dico "hic homo" demonstrando compositum ex anima et corpore, scilicet singulare.'

84 SH IV, P1, In1, Tr1, Q4, Ti1, D2, C4, p. 55: 'non tamen sequitur ex hoc quod assumpsit personam, quia per atomum, quod est idem quod individuum, non notatur nisi distinctio singularitatis vel incommunicabilitatis, non dignitatis, a qua sumitur ratio personae.' 
cede a separate human hypostasis to secure Christ's full humanity and sought to build their case for the unity of the God-man on an alternative conception of prosopon. ${ }^{85}$ Be this, however, as it may, it seems evident that the author of the Summa understood-to a certain point-what Damascus was saying in this passage and was content to use it against a popular Boethian theory without however committing himself to the particular view espoused by the Damascene. In fact, his citation of John's text as seemingly leading to an absurd consequence makes it easy for him to avoid serious consideration of the Eastern theologian's doctrinal and philosophical point of view.

B

My second case has arguably less intrinsic interest for the theology of the Summa but can serve as an illustration of what I have called earlier the ambiguous heritage of Peter Lombard's use of the Damascene. As we have seen, the Lombard cited a passage from The Orthodox Faith as if the Damascene had proposed that Christ's humanity was different in kind from that of other human beings. We recognise the effect of this distortion when the Summa ascribes to the authority of Damascus the single statement that 'one must not posit the common species in the Lord Jesus Christ'"86 and goes on to expound it as implying that the term 'homo' is used equivocally of Christ and other human beings.

This is then extensively discussed, but in the solution to objections, it turns out that the Franciscan author is perfectly aware that the basis of his earlier citation was a distortion of John's actual view. The Damascene simply meant to say, the Franciscan now explains correctly, that it is illicit to ascribe to Christ a common species 'mixed of divinity and humanity' (conflatam ex deitate et humanitate) as the heretics do. He then goes on to quote the clarifying words from John's book concluding that the Damascene by no means intended to deny that according to his humanity, the nature was predicated of Christ in the same way it is said of everyone else. ${ }^{87}$

To confuse things further, the author then adds that one might nonetheless understand John's original quotation in another, apparently less reproachable sense. After all, when predicated of other human beings, the nature expresses their whole being, while when predicated of Christ, it does not since it excludes his deity. ${ }^{88}$

85 Cf. Luise Abramowski, 'Die Christologie Babais des Großen,' in Symposium Syriacum 1972: Célébré dans les jours 26-31 octobre 1972 à l'Institut pontifical oriental de Rome: Rapports et communications (Rome: Pontificium Institutum Orientalium Studiorum, 1974), $219-44$.

86 SH IV, P1, In1, Tr1, Q4, Ti1, D2, C5, p. 56: 'non est sumere communem speciem in Domino Iesu Christo.'

87 SH IV, P1, In1, Tr1, Q4, Ti1, D2, C5, p. 57.

88 SH IV, P1, In1, Tr1, Q4, Ti1, D2, C5, p. 57. 
The purpose of this additional comment in the context of the Summa is not entirely clear, but the succession of John's truncated and misleading quotation evidently extracted from the Sentences, the solution on the basis of the context in The Orthodox Faith and, finally, the suggestion of a less objectionable interpretation of the original quote points quite distinctly to the source from which the Summa lifted the whole section: William of Auxerre's Summa Aurea. There, we find the exact same structure; the texts often agree nearly line by line:

\section{William of Auxerre, Summa Aurea ${ }^{89}$}

Illa autem auctoritas Iohannis Damasceni: 'Non est communem speciem predicare de Christo', sic est intelligenda, id est 'non' contingit 'predicare de Christo communem speciem' vel speciem conflatam ex duabus, scilicet ex deitate et humanitate. Hoc dixit lohannes Damascenus contra Euticium hereticum, qui dicebat quod Christus nec est Deus nec est homo, sed partim Deus, partim homo; et ita volebat quod quedam communis species confl(a)ta ex illis duabus, ita quod neutra illarum predicaretur de Christo.

Vel potest sic intelligi ilia auctoritas: 'Non est communem speciem' etc., id est 'non' contingit 'predicare de Christo communem speciem' communiter, quia hec species 'homo' si predicetur de Christo, sicut de aliis hominibus, non tamen ponitur communiter, id est communi modo, id est eo modo prorsus quo de aliis hominibus. De aliis enim hominibus ita predicatur quod comprehendit totum esse ipsorum, sed non comprehendit totum esse Christi, quia non comprehendit deitatem eius.

\section{Summa Halensis ${ }^{90}$}

Ad illud quod obicit de auctoritate Ioannis Damasceni quod 'in Domino lesu Christo non est communem speciem sumere' dicendum quod ita intelligit, quia non convenit de Christo dicere communem speciem conflatam ex deitate et humanitate, quae nec Deus esset nec homo, sicut dicebant haeretici, sicut patet per hoc quod subditur: 'Neque enim factus est neque aliquando fiet alius Christus.' Non negatur ergo quod, secundum quod homo, de ipso praedicetur ipsa communis species et univoce sicut de aliis. Vel potest intelligi aliter quod non prorsus eodem modo praedicatur de Christo et de aliis, quia praedicata de aliis comprehendit totum esse ipsorum, sed praedicata de Christo non comprehendit totum esse Christi, quia non comprehendit deitatem.

We can now reconstruct what happened: from Lombard's book, the single line according to which the common human species should not be predicated of Christ was distilled as an opinion of the Damascene. As such, it was integrated into the growing treasure of authoritative quotations. It was soon realised, however, that a simple look into the chapter from which the sentence was taken revealed that this rather extraordinary claim was not at all what the Damascene had intended to say. Still, this did not simply stop its further use. Indeed, we find that, in addition to the clarification of the Damascene's intention on the basis of the original source, there is developed another argument to protect the Greek father against the obviously dangerous inferences of his apparent statement. All of this is found side-by-side in

89 William of Auxerre, Summa Aurea III, tr. 1, c. 3. q. 9, 6-7 (Ribaillier, 4:38.105-39.119). 90 SH IV, P1, In1, Tr1, Q4, Ti1, D2, C5, p. 57. 
the Summa; it must be left to further, more detailed research to interpret this intriguing outcome.

C

So far, my method has been rather pedestrian, focussing on the use of Damascene texts in the section I chose from the Summa Halensis. On this basis, not much evidence has emerged for a positive influence of Eastern Patristic thought on the theology of the Summa. I would like to add one further observation which is of a rather different kind and inevitably more speculative.

In discussing the mode of the union, the Summa Halensis discusses a number of analogies including that of the union of soul and body in the human person. Ultimately, this analogy is discarded in favour of that of a branch grafted onto an existing tree. The point is clear: the body and soul analogy might suggest that two elements come together to form a third thing (unum, scilicet tertium, sit ex illis). ${ }^{91}$ The whole passage including the grafting model is not original to the Summa but found previously in Alain of Lille's Regulae theologicae. ${ }^{92}$ Nonetheless, the conceptual shift is remarkable. In the $12^{\text {th }}$ century, several major theologians, including Gilbert of Poitiers, Hugh of St Victor, and even Abelard had seen this analogy as valid in spite of their fundamental Christological disagreements. ${ }^{93}$ The reason was simple: the analogy was found literally in the Symbolum Quicumque which for Western Christians was an accepted creed. ${ }^{94}$ What can explain the sudden fall from favour of this model?

The argument that the body-soul analogy might be dangerous in that it suggests that the hypostatic union results in a third thing made out of two elements, is encountered in John of Damascus, as one would expect in the context of his criticism of miaphysite Christologies. The relevant passage is once again in Chapter 47 (III 3):

But we do not call Christ "of one composite nature" [1], nor "something else out of other [elements]" [2], in the way in which a human being [consists] of soul and body or the body of the four elements, but one and the same out of other [elements] [3]. ${ }^{95}$

91 SH IV, P1, In1, Tr1, Q4, Ti2, C1, p. 84.

92 Alain of Lille, Theologicae regulae 100 (PL 210:674B-675B).

93 Nielsen, Theology and Philosophy, 168 - 9 (for Gilbert), 201 (for Hugh of St Victor), 215-8 (for Abelard), and passim.

94 Cuthbert Hamilton Turner, 'A Critical Text of the Quicumque Vult,' Journal of Theological Studies 11 (1910): 410, n. 37.

95 John of Damascus, De fide orth. 47.2 [III 3] (Buytaert, 174.22-5): 'Nos autem, neque unius compositae naturae Christum nominamus neque ex aliis aliud, quemadmodum ex anima et corpore hominem, vel ut ex quatuor elementis corpus, sed ex aliis eadem.' 
John here proposes three options for the union in extremely brief and condensed form: mixture of two into one; constitution of a third out of two; and a hypostatic union of two natures. The first is the monophysite view; the second is problematic as well; the third is orthodox.

While admittedly neither Alain nor the Summa mention John of Damascus here, let alone this passage, the parallels are nonetheless remarkable. Both present the same options in the same order: The monophysite 'confusion'; then the body-soul analogy; finally, the (acceptable) grafting analogy. In this order, the three are presented in a more developed way and each with an illustrating analogy. At the end of their respective sections, both Alain and the author of the Summa offer a brief summary, and here they use the same formulaic style employed by the Damascene in his text.

Alain summarises as follows:

Body and soul are united to the Son of God; thus they are not the Son of God, but they are of the Son of God [3]. Thus [it results] that the Son of God does not consist of them and another [2], but in one person there are two natures, the divine remaining divine, the human remaining human. ${ }^{96}$

The Summa follows this quite closely:

The union then of humanity to the deity is such that one is made by and is of the other [3]. It is not a union in which one is the other [1] nor one in which a third item comes to be from those [two] [2]. ${ }^{97}$

While the Latin writers deviate from John's order in their brief summaries, they had followed it in their longer argument. Otherwise, parallels here abound with the Damascene's text. Interestingly, it is the Summa that is closest to the Greek theologian here. It preserves the three options and presents them in a kind of shorthand that strongly resembles Damascus' own formulation.

In the absence of an explicit reference to the Damascene, it is difficult to be unequivocal on this dependence. Yet circumstantial evidence appears strong to me not least in the face of the earlier popularity of the body-soul analogy. It would certainly not be without irony if it turned out that the strongest conceptual influence Damascus had on the Summa's Christology might well not be found where the book is explicitly cited but in more indirect and unacknowledged ways. It would show that, while the ideas of Damascus were in the mind of the Summa's authors as potential resources to be employed, the scholastic method did not constrain them in presenting those views either to do so exactly along the lines of their source or even in as-

96 Alain of Lille, Theologicae regulae 100 (PL 210:674 A-B): 'Similiter corpus et anima sunt Filio Dei unita, ita quod non sunt Filius Dei, sed sunt de Filio Dei; ita quod Filius Dei non constat ex illis, et alio; sed in una persona sunt duae naturae, divina manens divina, humana manens humana.'

97 SH IV, P1, In1, Tr1, Q4, Ti2, C1, p. 84: 'quod unio humanitatis ad deitatem est illa, in qua fit unum vel est de altera, et non in qua unum sit alterum nec in qua unum, scilicet tertium sit ex illis.' 
sociation with their original source, which could in its own right be twisted to contest or endorse views not indigenous to it. For the Patristic scholar this would, if anything, mark a return to a literary practice that was generally used and accepted for at least a millennium in the intellectual culture of Greek Christianity.

\section{Conclusion}

One final question needs to be addressed. If the Franciscan author of the Summa found most of the quotations he used from John of Damascus in previous Western literature, notably in Lombard's Sentences, was there any originality in his inclusion of these sources in his huge work? To answer this question, I propose to consider briefly the particular technique the Summa Halensis employed in making use of these extracts of the Damascene's work. The examples studied in this paper practically all illustrate this rather particular and, arguably, novel way of working with traditional authorities.

Citations, of course, have had their place in Christian literature from its very beginning. Often, and perhaps most straight-forwardly, they were introduced to bolster the author's own position by indicating its agreement with a traditional and accepted authority as, for example, in Patristic florilegia. Popular also, especially among polemicists, was the practice of citing opponents in their very words in order to ensure the full exposure of their doctrinal error as well as other depravities. Occasionally, ambiguous texts by accepted authorities had to be cited to stem their potential misinterpretation or abuse. Church historians or other archivists would adduce texts as part of an effort to document what happened in the past.

While this list may not be exhaustive, it serves to throw into sharp relief the idiosyncrasy of the Summa's use of quotations. The authority of John of Damascus is cited in support of the most extraordinary positions to which the author of the Summa obviously did not himself subscribe. Yet there is little evidence that the Franciscan writer was concerned that an eminent authority would have uttered such outrageous opinions; he certainly does not write to unmask the Damascene as a heretic. In fact, as we have seen, the quotations usually only appear problematic because they are taken out of context, truncated, or both.

Instead, what we seem to encounter in the Summa Halensis is the use of known sentences or brief excerpts for more or less purely dialectical purposes. They matter insofar as the thorough investigation of a doctrinal topos required the careful discussion of any potential objection to the teaching of the Church and the solution of any conceptual problem that might seem to exist in the doctrinal tradition. This use of proof texts, it seems, was still fairly novel at the time of the Summa. It is absent from Lombard's Sentences and still rather inchoate in William's Summa Aurea. It is, therefore, likely that it emerged as part of the new institutional and didactic context of the medieval university. The Summa's use of a large number of authoritative quotations should, I would thus conclude, be further analysed against this back- 
ground and as part of a newly emerging intellectual culture. The absolute number of explicit references to any given author may, by contrast, tell us relatively little about that person's intellectual influence on the theology of the Summa's authors. 
